\title{
EXTREME RADIAL GROWTH REACTION OF NORWAY SPRUCE ALONG AN ALTITUDINAL GRADIENT IN THE ŠUMAVA MOUNTAINS
}

\author{
ALŽBĚTA ČEJKOVÁ ${ }^{1,2}$ and TOMÁŠ KOLÁŘ ${ }^{2}$ \\ ${ }^{1}$ University of České Budějovice, Faculty of Science, \\ Branišovská 31, CZ-370 05, České Budějovice, Czech Republic \\ ${ }^{2}$ Administration of Orlické hory PLA, \\ Dobrovského 332, CZ-516 01, Rychnov nad Kněžnou, Czech Republic
}

Received 4 May 2009 Accepted 27 July 2009

\begin{abstract}
Extreme radial growth reactions were analyzed over a 79-year period (1922-2000) to compare response of Norway spruce (Picea abies [L.] Karst.) along an altitudinal gradient (376-1221 m a.s.l.) in the Šumava Mountains, the Czech Republic. Extreme growth events were defined as pointer years, when an average percentage of the site pointer years reached at least $50 \%$ strength observed at the relevant altitudinal zone (low < ca. $700 \mathrm{~m}$; middle ca. 700-950 m, high > ca. $950 \mathrm{~m}$ ). The comparison of the pointer years showed a specific pattern for altitudinal zones (Low: negative pointer years 2000, 1992, 1984, 1976, 1971 and positive 1997, 1975, 1960, 1949, 1932, 1926; middle: negative 2000,1992, 1976 and positive 1997, 1989, 1978; high: negative 1996, 1980, 1974, 1965 and positive 1989, 1963, 1927). Negative pointer years were usually induced by summer drought at low elevations and by wet-cold summer at high altitudinal zone. These two main limiting factors were probably combined at the middle altitudinal zone. Detailed understanding of the extreme tree ring pattern along the altitudinal and geographical scale may be used as one of the additional indicators of dendrochronological dating and provenance identification of spruce sample among altitudinal zones in the Šumava Mountains.
\end{abstract}

Keywords: dendrochronology, Picea abies, pointer years, altitudinal gradient.

\section{INTRODUCTION}

The methods of dendrochronology are an effective tool for analyzing the ecological relationship among tree species and environment (e.g. Fritts, 1976; Schweingruber, 1996). Tree-ring series contain an aggregation of a finite number of signals that represent the sum of the environmental influences on a tree growth (Cook and Kairiukstis, 1990). Climate signal is considered as one of the main controlling factors for the tree growth, and the tree response is modified by tree species, provenience, competition, site conditions etc. (Fritts, 1976; Vitas, 2004; Spiecker, 2002). To understand the relationship between the tree growth and complex actions of climate, correlation and response function analyses have been developed (Fritts, 1976; Cook and Kairiukstis, 1990).

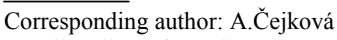

e-mail: cejkova@gmail.com
This approach ordinarily provides the concept about the average response of trees to the range of climate factors. Such information is very useful for studying climate reconstructions and climate changes over long periods (e.g. Rolland et al., 1998; Solberg et al., 2002; Esper et al., 2002; Wilson et al., 2005a; Wilson et al., 2005b). The above mentioned techniques have not revealed climatic forcing of single extreme years (e.g. Kienast et al., 1987). Analyses of extreme growth events and comparison with instrumental data serve for this purpose (Schweingruber et al., 1990) and could validate the temporal stability of the climate-growth relationship (Neuwirth et al., 2004). When such an event year is detected simultaneously in the majority of trees in the same population, it is named "pointer year". Only these extreme growth changes common for relevant altitudinal zone are comprised in this study. To illustrate the behavioral differences of the Norway spruce to extreme climatic conditions, we analyzed 17 Norway spruce (Picea abies [L.] Karst.) popula- 
tions along an altitudinal gradient $(370-1315 \mathrm{~m})$ in the Šumava Mountains. The main purpose of this study was to investigate a) the difference and change of frequency and strength of extreme tree rings of Norway spruce with increasing altitude, b) which extremes in the course of climate condition caused pointer years, c) whether such influences differ in various altitudinal zones.

Detailed understanding of the extreme tree ring pattern along the altitudinal and geographical scale may be used as one of the additional indicators of dendrochronological dating and provenance identification of spruce sample among altitudinal zones in the Sumava Mountains. We have repeatedly encountered problems with cross-dating of spruce historical construction timber from higher altitudes of the Šumava Mountains (Beneš et al., 2006).

\section{MATERIAL AND METHODS}

For this study, 17 sites of Norway spruce of relatively similar character were chosen along an altitudinal gradient in the Šumava Mountains and its foothills from ca. 375 to $1315 \mathrm{~m}$ a.s.l. (Table 1, Fig. 1). Most of the studied sites are plantations, particularly at low and middle elevations. In each stand, 20 dominant trees without visible signs of damage were selected as sample trees. Two increment cores were taken from each tree at the height of $1.3 \mathrm{~m}$ above ground.

Tree-ring widths were measured within $0.01 \mathrm{~mm}$ accuracy, using the measuring device (TimeTable) and the computer program Past32 (Knibbe, 2003). Tree-ring series with dissimilar growth were not used for the analysis of pointer years.

Pointer years for each stand were determined by the method of "Normalization in a moving window" (Cropper, 1979; this method was also described in Schweingruber et al., 1990 and Meyer, 1999). Extreme growth reaction within a sequence of an individual tree is called an event year, synchronous event years of one site are referred to as pointer years (Schweingruber et al., 1990).

In the first step, event years were calculated using a five-year moving window in each measured tree-ring width series following this formula:

$z_{i}=\frac{x_{i}-\operatorname{mean}[\text { window }]}{\text { stdev }[\text { window }]}$

$z_{i}-$ index value in the year $i$

$x_{i}$ - original value in the year $i$

mean [window] - arithmetic mean of the ring width within the window $x_{i-2}, x_{i-1}, x_{i}, x_{i+1}, x_{i+2}$

stdev [window] - standard deviation of the ring width within the window $x_{i-2}, x_{i-1}, x_{i}, x_{i+1}, x_{i+2}$

Negative and positive event years demand for threshold values of $z_{i}$, which were $z_{i} \geq-1$ and $\geq 1$.

In the second step, the site pointer year was determined when the event value recurred in at least $50 \%$ of tree-ring width series per population.

The pointer years of the 17 site chronologies were analyzed along an altitudinal gradient for the common time span of 1922-2000. The whole period of individual chronologies is longer (from 83 to 275 years, Table 1),

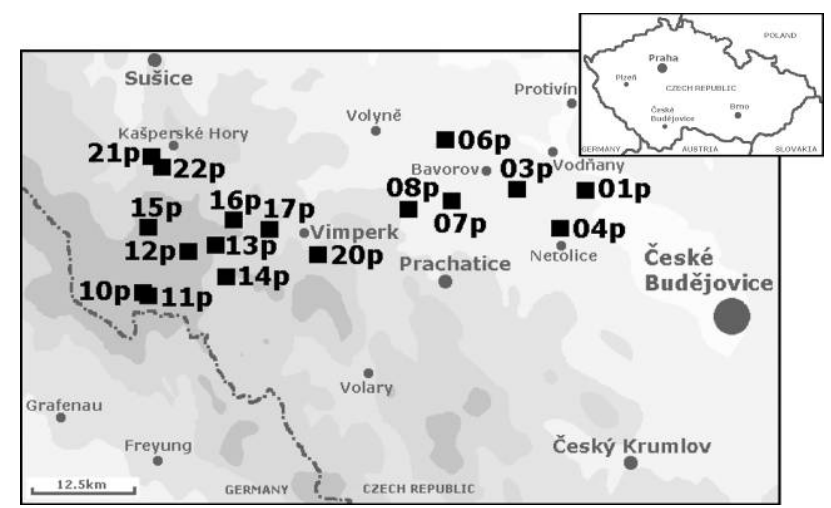

Fig. 1. Map of 17 study stands of Norway spruce along an altitudinal gradient (370-1 315 m) in the Šumava Mountains.

but the common interval with sufficient numbers of measurements for every stand started in 1922. In our previous study (Čejková and Koláŕ, 2005) we identified three categories of altitudinal zones (low < ca. $700 \mathrm{~m}$; middle ca. 700-950 m, high $>$ ca. $950 \mathrm{~m}$ ). Common altitudinal pointer years were determined for each of these altitudinal zones, and they were recognized when the average percentage of site pointer years reached at least $50 \%$.

For the climatic interpretation of pointer years meteorological data from České Budějovice (mean temperature and monthly sum of precipitation) were used. This series were used for its longer time period and relatively close distance of the study area.

\section{RESULTS AND DISCUSSION}

\section{Pointer years on the altitudinal gradient}

The analysis of pointer years found out five negative $(2000,1992,1984,1976,1971)$ and six positive pointer years $(1997,1975,1960,1949,1932,1926)$ for the low altitudinal zone, three negative $(2000,1992,1976)$ and three positive pointer years $(1997,1989,1978)$ for the middle altitudinal zone and four negative (1996, 1980, $1974,1965)$ and three positive pointer years $(1989,1963$, 1927) for the high altitudinal zone (Fig. 2).

The highest tree responses to the changes of the environmental factors are often observed at low altitudes and particularly on the southern slopes (Rolland et al., 2000). The same trend was determined for populations of Norway spruces at the low altitudinal zone of the Sumava foothills where the trees reacted more frequently than at the high altitudinal zone. Spruces had extreme growth reactions along the whole altitudinal gradients only since the 1960s and eminent abrupt reductions were higher than positive increments (Fig. 2). It could be a consequence of the negative correlation between the tree age and its treering width. Schweingruber (1986) demonstrated that younger trees were unable to react whereas the reactions of the mature individuals were obvious (Schweingruber, 1986). Another and probable explanation is the negative influence of air pollution (above all $\mathrm{SO}_{2}$ ) in central Europe (e.g. Visser and Molenaar, 1992; Wilson and Elling, 2004 - Bavarian forest-Germany; Sander et al., 1995 - Giant Mountain-Czech Republic). In the first part 
Table 1. Climatic interpretation of pointer years: - negative, + positive pointer year, $L-$ low altitudinal zone $(<c a .700 \mathrm{~m}), M$ - middle altitudinal zone (ca. 700-950 m), H- high altitudinal zone (> ca. $950 \mathrm{~m}$ ).

\begin{tabular}{|c|c|c|c|c|c|c|c|}
\hline $\begin{array}{l}\text { altitudinal } \\
\text { zone }\end{array}$ & $\begin{array}{l}\text { Sand } \\
\text { code }\end{array}$ & Location & $\begin{array}{c}\text { Altitude } \\
(\mathrm{m})\end{array}$ & $\begin{array}{l}\text { chronology } \\
\text { time span }\end{array}$ & $\begin{array}{c}\text { mean } \\
\text { age }\end{array}$ & $\begin{array}{l}\text { No. of radii } \\
\text { (trees) }\end{array}$ & Site description \\
\hline \multirow{6}{*}{ low } & $001 p$ & $\begin{array}{l}49^{\circ} 06^{\prime} 35,8^{\prime \prime} \mathrm{N} \\
14^{\circ} 13^{\prime} 36,6^{\prime \prime} \mathrm{E}\end{array}$ & 376 & 1908-2002 & 86 & $30(17)$ & $\begin{array}{l}\text { plain, mixed forest: Picea abies, Pinus } \\
\text { sylvestris with Rubus sp. }\end{array}$ \\
\hline & $003 p$ & $\begin{array}{l}49^{\circ} 06^{\prime} 08,1^{\prime \prime} \mathrm{N} \\
14^{\circ} 07^{\prime} 24,4^{\prime \prime} \mathrm{E}\end{array}$ & 537 & $1900-2001$ & 94 & $29(20)$ & $\begin{array}{l}\text { plain, spruce forest with Calamagrostis } \\
\text { epygejos }\end{array}$ \\
\hline & $004 p$ & $\begin{array}{l}49^{\circ} 04^{\prime} 26,1^{\prime \prime} \mathrm{N} \\
14^{\circ} 11^{\prime} 24,9^{\prime \prime} \mathrm{E}\end{array}$ & 480 & 1883-2002 & 105 & $27(17)$ & $\begin{array}{l}\text { plain, mixed forest: Picea abies, Pinus } \\
\text { sylvestris with Avenella flexuosa }\end{array}$ \\
\hline & $006 p$ & $\begin{array}{l}49^{\circ} 09^{\prime} 03,8^{\prime \prime} \mathrm{N} \\
14^{\circ} 00^{\prime} 29,0^{\prime \prime} \mathrm{E}\end{array}$ & 624 & 1884-2002 & 91 & $27(16)$ & $\begin{array}{l}\text { west gentle slope }\left(5^{\circ}\right) \text { mixed forest: Picea } \\
\text { abies, Abies alba with Calamagrostis } \\
\text { arundinacea }\end{array}$ \\
\hline & $007 p$ & $\begin{array}{l}49^{\circ} 05^{\prime} 11,4^{\prime \prime} \mathrm{N} \\
14^{\circ} 01^{\prime} 07,9^{\prime \prime} \mathrm{E}\end{array}$ & 520 & 1908-2002 & 81 & $23(17)$ & $\begin{array}{l}\text { plain, mixed forest: Picea abies, Pinus } \\
\text { sylvestris, Larix decidua with Carex } \\
\text { brizoides }\end{array}$ \\
\hline & $008 p$ & $\begin{array}{l}49^{\circ} 04^{\prime} 16,9^{\prime \prime} \mathrm{N} \\
13^{\circ} 55^{\prime} 53,2^{\prime \prime} \mathrm{E}\end{array}$ & 698 & $1910-2002$ & 81 & $18(14)$ & $\begin{array}{l}\text { plain and gentle slope, mixed forest: } \\
\text { Picea abies, Abies alba, Pinus sylvestris } \\
\text { with Calamagrostis arundinacea }\end{array}$ \\
\hline \multirow{7}{*}{ high } & $010 p$ & $\begin{array}{l}48^{\circ} 58^{\prime} 45,2^{\prime \prime} \mathrm{N} \\
13^{\circ} 33^{\prime} 02,7^{\prime \prime} \mathrm{E}\end{array}$ & 1313 & $1857-2002$ & 118 & $26(14)$ & $\begin{array}{l}\text { summit site, spruce forest with Calama- } \\
\text { grostis villosa }\end{array}$ \\
\hline & $011 p$ & $\begin{array}{l}48^{\circ} 58^{\prime} 38,2^{\prime \prime} \mathrm{N} \\
13^{\circ} 33^{\prime} 29,0^{\prime \prime} \mathrm{E}\end{array}$ & 1255 & $1865-2002$ & 111 & $23(15)$ & $\begin{array}{l}\text { small plain in east slope }\left(10^{\circ}\right) \text {, spruce } \\
\text { forest with Calamagrostis villosa }\end{array}$ \\
\hline & $012 p$ & $\begin{array}{l}49^{\circ} 02^{\prime} 16,4^{\prime \prime} \mathrm{N} \\
13^{\circ} 34^{\prime} 54,3^{\prime \prime} \mathrm{E}\end{array}$ & 1118 & $1839-2002$ & 110 & $28(17)$ & $\begin{array}{l}\text { plain, spruce forest with Avenella flexu- } \\
\text { osa }\end{array}$ \\
\hline & $013 p$ & $\begin{array}{l}49^{\circ} 02^{\prime} 22,7^{\prime \prime} \mathrm{N} \\
13^{\circ} 37^{\prime} 08,1^{\prime \prime} \mathrm{E}\end{array}$ & 1218 & $1837-2002$ & 136 & $27(15)$ & $\begin{array}{l}\text { summit site, spruce forest with Calama- } \\
\text { grostis villosa }\end{array}$ \\
\hline & $014 p$ & $\begin{array}{l}49^{\circ} 00^{\prime} 10,8^{\prime \prime} \mathrm{N} \\
13^{\circ} 37^{\prime} 51,2^{\prime \prime} \mathrm{E}\end{array}$ & 1047 & $1858-2002$ & 124 & $28(16)$ & $\begin{array}{l}\text { southwest slope }\left(5^{\circ}\right) \text {, spruce forest with } \\
\text { Calamagrostis villosa }\end{array}$ \\
\hline & $015 p$ & $\begin{array}{l}49^{\circ} 00^{\prime} 10,8^{\prime \prime} \mathrm{N} \\
13^{\circ} 37^{\prime} 51,2^{\prime \prime} \mathrm{E}\end{array}$ & 1221 & $1729-2002$ & 177 & $32(19)$ & $\begin{array}{l}\text { plain in southwest slope }\left(10^{\circ}\right) \text {, spruce } \\
\text { forest with Calamagrostis villosa }\end{array}$ \\
\hline & $016 p$ & $\begin{array}{l}49^{\circ} 03^{\prime} 12,8^{\prime \prime} \mathrm{N} \\
13^{\circ} 39^{\prime} 54,7^{\prime \prime} \mathrm{E}\end{array}$ & 979 & 1736-2002 & 190 & $30(17)$ & $\begin{array}{l}\text { plain, spruce forest with Calamagrostis } \\
\text { villosa }\end{array}$ \\
\hline \multirow{4}{*}{ middle } & $017 p$ & $\begin{array}{l}49^{\circ} 03^{\prime} 32,2^{\prime \prime} \mathrm{N} \\
13^{\circ} 42^{\prime} 54,9^{\prime \prime} \mathrm{E}\end{array}$ & 946 & $1901-2002$ & 93 & $29(15)$ & $\begin{array}{l}\text { southeast gentle slope }\left(5^{\circ}\right) \text {, spruce forest } \\
\text { with Avenella flexuosa and Vaccinium } \\
\text { myrtillus }\end{array}$ \\
\hline & $020 p$ & $\begin{array}{l}49^{\circ} 01^{\prime} 54,8^{\prime \prime} \mathrm{N} \\
13^{\circ} 48^{\prime} 29,8^{\prime \prime} \mathrm{E}\end{array}$ & 835 & $1910-2002$ & 86 & $19(10)$ & $\begin{array}{l}\text { gentle slope and plain, spruce forest with } \\
\text { Avenella flexuosa and Vaccinium myrtil- } \\
\text { lus }\end{array}$ \\
\hline & $021 p$ & $\begin{array}{l}49^{\circ} 08^{\prime} 09,5^{\prime \prime} \mathrm{N} \\
13^{\circ} 30^{\prime} 45,6^{\prime \prime} \mathrm{E}\end{array}$ & 842 & $1879-2004$ & 105 & $34(19)$ & $\begin{array}{l}\text { plain, mixed forest: Picea abies, Pinus } \\
\text { sylvestris, Abies alba with Vaccinium } \\
\text { myrtillus }\end{array}$ \\
\hline & $022 p$ & $\begin{array}{l}49^{\circ} 06^{\prime} 43,4^{\prime \prime} \mathrm{N} \\
13^{\circ} 33^{\prime} 25,2^{\prime \prime} \mathrm{E}\end{array}$ & 760 & 1849-2004 & 110 & $28(18)$ & $\begin{array}{l}\text { east gentle slope }\left(5^{\circ}\right) \text {, mixed forest: } \\
\text { Picea abies, Abies alba, Fagus sylvestris, } \\
\text { Tilia cordata with Calamagrostis villosa }\end{array}$ \\
\hline
\end{tabular}

of the analyzed time span (1922-1960), the trees reacted only extremely positively in the low altitudinal zone, weakly in the high altitudinal zone and no reaction was found by means of this calculation method in the middle altitudinal zone. Most positive growth responses are caused by a local combination of favorable climatic factors rather than simple extreme events, and therefore they are less efficient for wood dating (Rolland et al., 2000).

Pointer years were specific in the low and high altitudinal zones. The middle altitudes comprised a transition area with pointer years identical with the abovementioned zones (particularly with low altitudes), but pointer years differ in intensity, i.e. trees reacted less frequently and the response was weaker (Figs. 2 and 3). This situation probably shows the ambiguous reaction of trees to external environmental conditions that switch from those limiting either for high or low altitudes. The influence of climatic conditions on tree growth becomes stronger with the ecological limits of the species (Fritts, 1976). In this case, the abiotic ecological limit of the spruce is at low altitudes; the centre of the occurrence of Picea abies is the mountainous (750-1100 $\mathrm{m}$ a.s.1.) and above all the supramountainous zone (1000-1370 m) in the Czech Republic (Skalický and Skalická, 1988). Trees growing in average climatic conditions react in a weaker way to the changes of climatic factors and the relationship between radial increment and climatic conditions may be more complex in average conditions. The factors that affect radial increment may change from year-to-year (Mäkinen et al., 2003).

\section{Climatic interpretation of pointer years and the large- scale comparison for Europe}

In the low altitudinal zone, the expression of negative pointer years (years: 1971, 1976, 1984, 1992, 2000; 


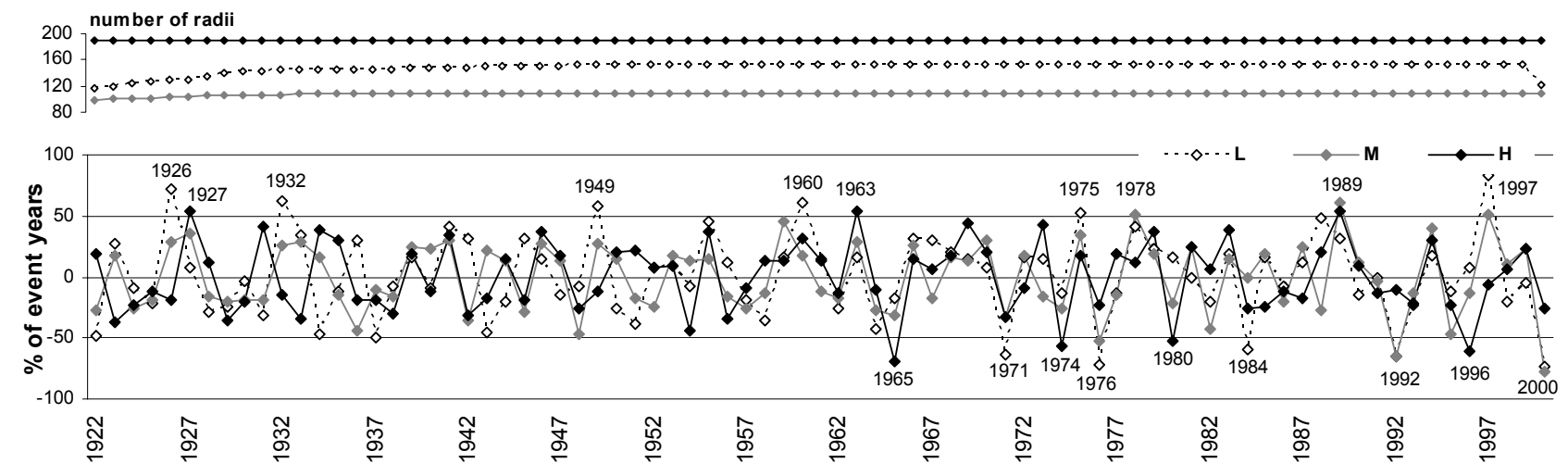

Fig. 2. The curves represent averaged percentage of site pointer values for the low $(L)$, middle $(M)$ and high $(H)$ altitudinal zones. Labelled pointer years are only obtained when average percentage of site pointer years reached at least $50 \%$ strength of observing.

Fig. 3a, Table 2) is probably connected with an insufficient amount of precipitation during the vegetation period (above all in May and June) and with the drought during a part of the vegetation period of the previous year. The lack of water usually interacts with warm temperatures in spring and summer that increase dehydration of the tree and result in a negative relationship between ring-width and temperature (Dittmar and Elling, 1999). The strong impact of drought coincided above all with the beginning of vegetation; mainly during tree-ring formation (Rolland et al., 1999; Vitas, 2001).

Positive pointer years are, to the contrary, connected with enough precipitation during the growing season (1926, 1932, 1949, 1960, 1975, 1997; Fig. 3, Table 2). It corresponds with the findings that in central Europe the annual growth of the Norway spruce was mainly related to precipitation (e.g. Koprowski and Zielski, 2006; Mäkinen et al., 2002; Wilson and Hopfmueller, 2001 ), and dry summers were connected to lower growth rates (cf. Eckstein et al., 1989; Spiecker, 1991). A typical positive pointer year of low elevations was 1932. The initiation of tree-ring formation was positively influenced by high precipitation and below-average temperature above all in May; similar situation with a rainy but warmer than usual summer led to larger ring widths in Southern French and Italian Alps (Rolland et al., 2000) and the north foothill of the Alps in Switzerland (Schweingruber et al., 1991).

On the other hand, the drought period from May to August induced the highest growth reduction (Schweingruber, 1986). The Norway spruce is very sensitive to drought due to its superficial root system (Chmelar̆, 1986). This is the cause of the negative pointer year of

Table 2. Climatic interpretation of pointer years: - negative, + positive pointer year, $L$ - low altitudinal zone $(<\mathrm{ca} .700 \mathrm{~m}), M$ - middle altitudinal zone (ca. 700-950 m), $\mathrm{H}$ - high altitudinal zone (> ca. $950 \mathrm{~m}$ ).

\begin{tabular}{l|c|c|l}
\hline 2000 & - & L-M & dry and hot spring and early summer, dry previous spring to autumn (1999) \\
1997 & + & L-M & rainy summer, warm and wet end winter and early spring \\
1996 & - & H & severe winter, rainy spring and cold summer \\
1992 & - & L-M & dry and hot spring and summer \\
1989 & + & H-M & mild winter and early spring and relatively dry late spring and summer \\
1984 & - & L & dry almost entire period - May 1983 to August 1984 \\
1980 & - & H & extremely cold growing season and after warm December cold January in combination with relatively small precipitation in this \\
1978 & + & M & period \\
1976 & - & L-M & extremely dry late winter to early summer and relatively hot in summer, after warm January cold February and March \\
1975 & + & L & wet summer and wet summer in previous year (1974) and mild winter \\
1974 & - & H & cold and rainy growing season, dry autumn in previous year (1973) and dry and warm period at the winter \\
1971 & - & L & relatively dry late spring and summer in previous year (1970), dry and cold January and May, dry July \\
1965 & - & H & cold wet year \\
1963 & + & H & relatively hot summer with low precipitation but severe winter - relationship unclear \\
1960 & + & L & wet and relatively cold year, above all summer and rainy late spring and summer in previous year (1959) \\
1949 & + & L & rainy spring and summer \\
1932 & + & L & rainy May and July and warmer than usually in July and August \\
1927 & + & H & mild winter and early summer, wet summer and autumn in previous year (1928) \\
1926 & + & L & wet and cold late spring and summer, mild winter and wet previous summer (1925) \\
\hline
\end{tabular}



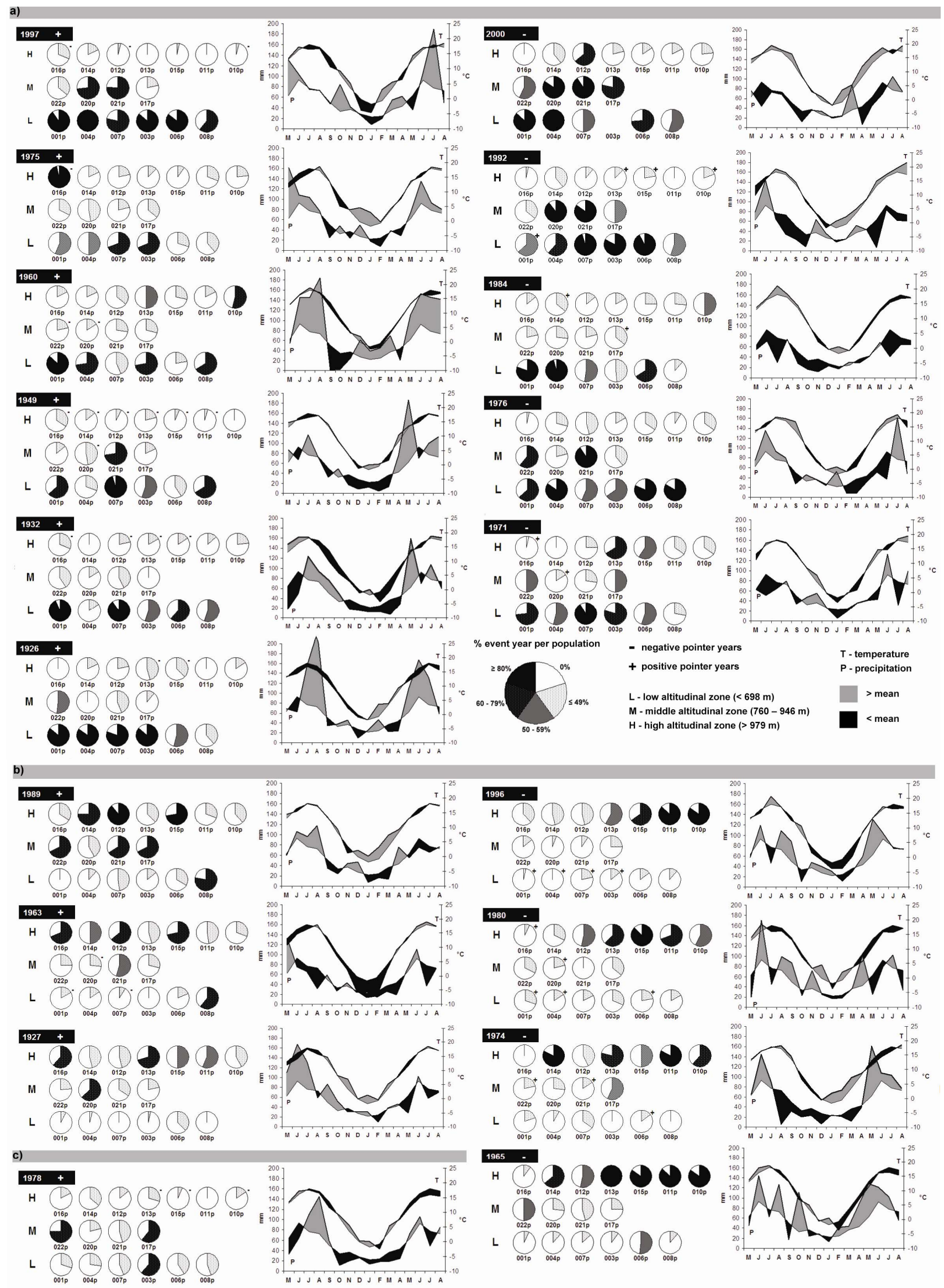

Fig. 3. Altitudinal variability of pointer years with temperature $(T)$ and precipitation $(P)$ data (mean long term data 1921-2000 and monthly values) for previous vegetation season and current year (from May of previous to September current year). Pie charts show in colored part the percentage of event years per population (The pointer year was determined, when event value was detected at least by $50 \%$ of tree-ring width series per population). a) Low altitudinal zone, b) high altitudinal zone, c) middle altitudinal zone. 
1992 in the low and middle altitudinal zones in the Šumava Mountains. This drought year also had a negative impact on spruce growth in the southern French and Italian Alps (Desplanque et al., 1999, Rolland et al., 2000), in Swiss Alps (Neuwirth et al., 2004) or in the whole Lithuania on wet sites (Vitas, 2004). The most important negative year occurred in many regions of Europe in 1976, especially at lower elevations (Swiss, French and Italian Alps - Lingg, 1986; Schweingruber et al., 1991; Desplanque et al., 1999; Rolland et al., 2000, Neuwirth et al., 2004; Germany - Becker et al., 1990; Mäkinen et al., 2002; Southern Norway and Finland - Mäkinen et al., 2002). It was also detected at the elevation bellow $950 \mathrm{~m}$ a.s.l. in the Šumava Mountains and the foothills. 1976 was dry and warm, which prolonged the water deficit. This situation was repeated in the other sites in the Czech Republic, specifically in the Ore and Giant Mountains, but growth depression was detected in the trees bellow 800 m (Kroupová, 2002).

Generally, it is assumed that in the mountainous areas, the main driving factor of the tree growth is the temperature (Tranquillini, 1979; Rochefort et al., 1994; Rolland et al., 1998; Desplanque et al., 1999; Koprowski and Zielski, 2006). At high elevations in southern Germany, spruce chronologies (>800-900 $\mathrm{m}$ ) are more influenced by the temperature rather than precipitation (Dittmar and Elling, 1999). In the Czech part of the Šumava Mountains, the temperature could not be the main driving factor of ring-width formation, because this region does not reach the upper tree-line limit (Moravec, 1964; Skalický, 1998) and the trees from higher sites may not therefore demonstrate as strong response to the temperature as they would at a temperature of upper tree-line (Wilson and Hopfmueller, 2001). Positive pointer years are usually caused by low sums of precipitation and the average temperature or slightly higher temperature during the growing season (1927, 1963, 1989; Fig. 3b, Table 2) and negative pointer years with the cold especially in July and wet vegetation season (1965, 1974, 1980, 1996; Fig. 3b, Table 2). The intensive growth of the Norway spruce is connected with the summer months of June and July in the mountains (Kroupová, 2002, Savva et al., 2006) and the excessive June rainfall that are unfavorable for the ring formation at high elevations (Despalnque et al., 1999).

For instance, the stronger negative pointer year 1965 was very rainy and cold. This year was detected at the majority of sites and also in the other part of the Sumava Mountains (Trojmezná forest - Svoboda and Tichý, 2004), in Europe, for example in the French and Swiss Alps (Desplanque et al., 1999; Neuwirth et al., 2004). A similar response to extremely cold summer was observed in the high altitude zone in 1980, which is in a good agreement with the observations from Trojmezná (Svoboda and Tichý, 2004), the northern foothills of Swiss Alps (Schweingruber, 1986; Schweingruber et al., 1991) and wet sites in Lithuania (Vitas, 2004). Kroupová (2002) also connected the negative pointer year 1980 with the high concentration of air pollution during winter for localities above $1000 \mathrm{~m}$ in the Giant and Ore Mountains (Czech Republic).
Negative pointer year 1996 seems to be untypical; growth reduction was probably induced by a harsh winter in combination with a wet and cold vegetation season (Savva et al., 2006). Furthermore, the frozen soil may have prevented trees from absorbing soil water in March (Roland et al., 1999). The same reduction was noted in the Ore Mountains (Kroupová, 2002), where it was connected with winter frosts and high $\mathrm{SO}_{2}$ concentrations. Frost resistance of Norway spruce is decreased by longterm high concentrations of $\mathrm{SO}_{2}$ during winter (e.g. Spálený, 1980). A relatively similar coincidence could also occur in the Šumava Mountains, because the highest $\mathrm{SO}_{2}$ concentrations in this decade was recorded for Prachatice region in 1996 (Hruška and Cienciala, 2003).

The occurrence of pointer years could be a consequence of other effects, e.g. defoliation caused by insect, mast year etc. (Schweingruber, 1996). In southern Finland, the low growth of the Norway spruce has often coincided with the production of a rich seed crop, which requires large amounts of photosynthetic products (Mäkinen et al., 2002). For example, negative pointer years 1974 or 1976, usually connected with dry years, and are also related with mast years (Selås et al., 2002). This is a probable explanation also for the negative pointer years 1980, 1971 and 1992 because they represented mast years of the Norway spruce for the whole Czech Republic.

\section{ACKNOWLEDGEMENTS}

The authors thank for anonymous reviewers for their critical and helpful comments on this paper and Englishspeaking friends for improving our English. This research was supported by Ministry of Education of the Czech Republic grants FRVŠ 1849/2003, FRVŠ 40/2006 and MSM6007665801.

\section{REFERENCES}

Becker M, Bräker OU, Kenk G, Schneider O, Schweingruber FH, 1990. Kronenzustand und Wachstum von Waldbäumen im Dreiländereck Deutschland-Frankreich-Schweiz in den letzten Jahrzehnten (Crown condition and tree growth in the border areas of Germany, France, and Switzerland in the last century). Allgemeine Forst Zeitschrift 62(11): 267-274 (in German).

Beneš J, Kolář T and Čejková A, 2006. Xylotomic and dendrochronological analyses in archeology: Changes in the composition type of wood in Prague an in Southern Bohemia. Ve službách arceologie VII: 159-169.

Chmelař J, 1986. Dendrologie s ekologii lesnich dřevin (Dendrology with ecology of tree species). Brno, Vysoká škola zemědělská: 119pp (in Czech).

Cook ER and Kairiukstis LA, 1990. Methods of Dendrochronology, Applications in the Environmental Sciences. Dodrecht, Boston, London, Kluwer Academic Publishers: 394pp.

Cropper JP, 1979. Tree-ring skeleton plotting by computer. Tree-Ring Bulletin 39: 47-60.

Čejková A and Kolář T, 2005. Dendrochronological Investigations of the Šumava Mountains and the Šumava Foothills, Czech Republic. EuroDendro 2005, International Conference of Dendrochronology, Conference Abstract, Viterbo, Italy: 44-45.

Desplanque C, Rolland C and Schweingruber FH, 1999. Influence of species and abiotic factors on extreme tree ring modulation: Picea abies and Abies alba in Tarantaise and Maurienne (French Alps). Trees 13: 218-227.

Dittmar C and Elling W, 1999. Jahrringbreite von Fichte und Buche in Abhängigkeit von Witterung und Höhenlage (Radial growth of Norway spruce and European beech in relation to weather and alti- 
tude). Forstwissenschaftliches Centralblatt 118(4): 251-270 (in German).

Eckstein D, Krause C and Bauch J, 1989. Dendroecological investigation of spruce trees (Picea abies (L.) Karst.) of different damage and canopy classes. Holzforschung 43(6): 411-417.

Esper J, Cook ER and Schweingruber FH, 2002. Low-frequency signals in long tree-ring chronologies for reconstructing past temperature variability. Science 295: 2250-2253, DOI: $10.1126 /$ science. 1066208

Fritts HC, 1976. Tree Rings and Climate. New York, Academic Press: $567 \mathrm{pp}$.

Hruška J and Cienciala E, eds., 2003. Long-term acidification and nutrient degradation of forest soils - limiting factors of forestry today. Praha, Ministerstvo životního prostředí: 189pp (in Czech).

Kienast F, Schweingruber FH, Bräker OL and Schär E 1987. Tree-ring studies on conifers along ecological radients and the potential of single-year analyses. Canadian Journal of Forest Research 17: 683-696.

Knibbe B, 2003. Past32 Build 700 User Manual. Wien, Sciem: 90pp.

Koprowski M, Zielski A 2006. Dendrochronology of Norway spruce (Picea abies (L.) Karst.) from two range centres in lowland Poland. Trees - Structure and Function 20(3): 383-390.

Kroupová M, 2002. Dendroecological study of spruce growth in regions under long-term air pollution load. Journal of Forest Science 48: 536-548.

Lingg W, 1986. Dendroökologische Studien an Nadelbäumen im alpinen Trockental Wallis (Schweiz). Berichte der Eidgenössischen Anstalt für das forstliche Versuchswesen 287: 3-81.

Mäkinen H, Nöjd P, Kahle H-P, Neumann U, Tveite B, Mielikäinen K, Röhle H and Spiecker H, 2002. Radial growth variation of Norwey spruce (Picea abies (L.) Karst.) across latitudinal and altitudinal gradients in central and northern Europe. Forest Ecology and Management 171: 243-259.

Mäkinen H, Nöjd P, Kahle H-P, Neumann U, Tveite B, Mielikäinen K, Röhle H and Spiecker H, 2003. Large-scale climatic variability and radial increment variation Picea abies (L.) Karst.) in central and northern Europe. Trees 17: 173-184.

Meyer FD, 1999. Pointer year analysis in dendroecology: A comparison of methods. Dendrochronologia 16-17: 193-204.

Moravec J, 1964. Vegetační poměry Šumavy (Vegetation conditions of the Šumava Mountains). Ochrana prírody 19: 66-69 (in Czech).

Neuwirth B, Esper J, Schweingruber FH, Winiger M, 2004. Site ecological differences to the climatic forcing of spruce pointer years from Lötschental, Switzerland. Dendrochronologia 21(2): 69-78.

Rolland C, Petitcolas V, Michalet R, 1998. Changes in radial tree growth for Picea abies, Larix decidua, Pinus cembra and Pinus uncinata near the alpine timberline since 1750. Trees 13: 40-53.

Rolland C, Michalet R, Desplanque C, Petetin A and Aimé S, 1999. Ecological requirements of Abies alba in the French Alps derived from dendro-ecological analysis. Journal of Vegetation Science 10: 297-306.

Rolland C, Desplanque C, Michalet R, Schweingruber FH, 2000. Extreme tree rings in spruce (Picea abies [L.] Karst.) and fir (Abies alba Mill.) stands in relation to climate, site, and space in the southern French and Italian Alps. Artic, Antarctic, and Alpine Research 32: 1-13.

Rochefort RM, Little RL, Woodward A, Peterson DL, 1994. Changes in subalpine tree distribution in western North America: Effects of climate and other environmental factors. The Holocene 4: 89-100.

Sander C, Eckstein D, Kyncl J and Dobry J, 1995. The growth of spruce (Picea abies (L.) Karst.) in the Krkonose-(Giant) Mountain as indicated by ring width and wood density. Annales des Sciences forestières 52: 401-410.

Savva Y, Oleksyn J, Reich PB, Tjoelker MG, Vaganov EA, Modrzynski J 2006. Interannual growth response of Norway spruce to climate along an altitudinal gradient in the Tatra Mountains, Poland. Trees
- Structure and Function 20(6): 735-746.

Selås V, Piovesan G, Adams JM and Bernabei M, 2002. Climatic factors controlling reproduction and growth of Norway spruce in southern Norway. Canadian Journal of Forest Research 32(2): $217-225$.

Schweingruber FH, 1986. Abrupt growth changes in conifers. IAWA Bulletin n. s. 7(4): 277-283.

Schweingruber FH, 1996. Tree Rings and Environment Dendroecology. Birmensdorf, Swiss Federal Institute for Forest, Snow and Landscape Research. Berne, Stuttgart, Vienna, Haupt: 609pp.

Schweingruber FH, Eckstein D, Serre-Bachet F and Bräker OU, 1990. Identification, presentation and interpretation of event years and pointer years in dendrochronology. Dendrochronologia 8: 9-38.

Schweingruber FH, Wehrli U, Aellen-Rumo K and Aellen M, 1991. Weiserjahre als Zeiger extremer Standortseinflüsse (A dendrochronological study on trees near an incineration dump). Schweizerische Zeitschrift für Forstwesen 142: 33-52 (in German).

Skalický V 1998. Fytogeografický rozbor květeny Šumavy a přilehlých území (Phytogeographical study of flora of The Šumava Mountains and the closed regions). Zprávy České Botanické společnosti, 32: 117-121 (in Czech).

Skalický V and Skalická A, 1988. Picea A. Dieter-smrk. In: Hejný S and Slavík B, eds., Květena ČR 1, Academia, Praha: 317-322 (in Czech).

Solberg BO, Hofgaard A and Hytteborn H, 2002. Shifts in radial growth responses of coastal Picea abies induced by climatic change during the 20th century, central Norway. Ecoscience 9(1): 79-88.

Spálený J, 1980. Vliv kourových imisí na mrazuvzdornost smrku ztepilého (Influence of fumous immisions on frost-tolerance of Norway spruce). Lesnická práce 59: 411-414 (in Czech).

Spiecker H, 1991. Growth variation and environmental stress:long-term observations on permanent research plots in southwestern Germany. Water Air Soil Pollution 54: 247-256.

Spiecker H, 2002. Tree rings and forest management in Europe. Dendrochronologia 20(1-2): 191-202.

Svoboda M and Tichý T, 2004. Struktura a dynamika lesních porostů a kvantitativní a kvalitativní charakter odumřelé dřevní biomasy v oblasti Trojmezenského pralesa (Structure and dynamics of forest and quantitative and qualitative character dead woody biomass in the area of Trojmezná forest). AOPK, Praha. Príroda: 299-310 (in Czech).

Tranquillini W, 1979. Physiological Ecology of Alpine Timberline, Tree Existence at High Altitudes with Special Reference to the European Alps. Ecological Studies 31. Berlin, Heidelberg, New York, Springer-Verlag: $137 \mathrm{pp}$.

Visser H and Molenaar J, 1992. Estimating trends and stochastic functions in dendroecology with an application to fir decline. Forest Science 38(2): 221-234

Vitas A, 2004. Tree rings of Norway spruce (Picea abies (L.) Karsten) in Lithuania as drought indicators: dendroecological approach. Polish Journal of Ecology 52(2): 201-210.

Wilson RJS and Hopfmueller M, 2001. Dendrochronological investigations of Norway spruce along an elevational transect in the Bavarian Forest, Germany. Dendrochronologia 19(1): 67-79.

Wilson R and Elling W, 2004. Temporal instability in treegrowth/climate response in the Lower Bavarian Forest region: implications for dendroclimatic reconstruction. Trees - Structure and Function 18(1): 19-28.

Wilson RJS, Luckman BH and Esper J, 2005a. A 500 year dendroclimatic reconstruction of spring-summer precipitation from the lower Bavarian Forest region, Germany. International Journal of Climatology 25(5): 611-630.

Wilson R, Frank D, Topham J, Nicolussi K and Esper J, 2005b. Spatial reconstruction of summer temperatures in Central Europe for the last 500 years using annually resolved proxy records: problems and opportunities. Boreas 34(4): 490-497. 